\title{
ANALISIS PRODUK DARAH: KONTAMINASI BAKTERI PADA THROMBOCYTE CONCENTRATE
}

\section{ANALYSIS OF BLOOD PRODUCT: BACTERIAL CONTAMINATION IN THROMBOCYTE CONCENTRATE}

\author{
Serafica Btari Christiyani Kusumaningrum ${ }^{1 *}$, Wiwit Sepvianti ${ }^{2}$ \\ *1 Stikes Guna Bangsa Yogyakarta, Jalan Ringroad Utara Condong Catur Sleman Yogyakarta, \\ email: seraficabtarick@gmail.com, Indonesia \\ ${ }^{2}$ Stikes Guna Bangsa Yogyakarta, Jalan Ringroad Utara Condong Catur Sleman Yogyakarta, \\ email: wiwitsepvianti@gmail.com Indonesia
}

\begin{abstract}
Background: Bacterial contamination in thrombocyte concentrate (TC) blood product becomes a serious problem since it can cause clinical risks from mild symptom to death. TC storage condition at $22-25^{\circ} \mathrm{C}$ with agitation is good condition for bacterial growth. Source of bacterial contamination can come from donor bacteremia, not aseptically from taking and processing blood product. In a previous study, showed there were positive gram bacteria as bacterial contamination in TC.

Objective: This objective aims to determine bacterial contaminants in TC blood products.

Methods: Total of 3 TC bag samples were collected from UDD PMI Kabupaten Sleman. Each sample was inoculated to nutrient agar media and it incubated for 48 jam at $37^{\circ} \mathrm{C}$. Observation of bacterial colony growth is carried out after incubation time is over.

Results: There was no bacterial growth in the media so that there was no bacterial contamination in TC. It showed that the procedures, processing, and storage of TC products in PMI Kabupaten Sleman were aseptic. Besides that, TC donors also did not suffer from bacteremia so there was bacterial contamination in TC.

Conclusion: In this study, bacterial contamination in blood product TC was not found since there was no bacterial growth in media.
\end{abstract}

Keywords: Bacterial contamination, blood products, blood bank, thrombocyte concentrate.

\section{PENDAHULUAN}

Transfusi darah merupakan upaya perawatan kesehatan dengan memindahkan darah donor kepada pasien yang dilakukan pada beberapa kondisi seperti anemia kronik, kelainan darah dan pendarahan massif. ${ }^{1}$ Transfusi darah dalam upaya perawatan kesehatan tidak terlepas dari risiko seperti reaksi hemolitik, akumulasi cairan, infeksi virus, kontaminasi bakteri, dan reaksi alergi. ${ }^{2}$ Berdasarkan penelitian sebelumnya ${ }^{3}$ risiko transfusi akibat kontaminasi bakteri pada produk darah masih menjadi permasalahan yang serius di Indonesia karena keterbatasan alat untuk mendeteksi bakteri kontaminan hampir di seluruh unit donor darah (UDD). Sumber kontaminasi bakteri dapat disebabkan dari bakteremia pendonor, kontaminasi dari permukaan kulit selama prosedur pengambilan dan pengolahan produk darah. ${ }^{4}$ Produk darah thrombocyte concentrate (TC) dapat menjadi sumber kontaminasi bakteri karena penyimpanan TC berada pada suhu $20-24^{\circ} \mathrm{C}$, penyimpanan pada kantong gas-permeabel dengan proses agitasi dapat menjadi tempat pertumbuhan yang baik bagi bakteri. ${ }^{4,5}$ Selain itu, TC juga disimpan dengan penambahan pengawet 
seperti laktat dan carnitin yang berfungsi untuk mempertahankan viabilitas trombosit, namun juga dapat mendukung pertumbuhan bakteri. ${ }^{6,7}$

Penelitian yang dilakukan di China menyatakan bahwa terdapat 44 kantong TC dari 28.711 kantong TC mengandung bakteri kontaminan yang berpotensi menimbulkan reaksi transfusi. ${ }^{8}$ Kasus kontaminasi bakteri pada platelet yang terjadi di California dan Utah menyebabkan kematian pasien setelah transfusi trombosit akibat sepsis bakteri patogen pada pasien. ${ }^{9}$ Oleh karena itu, kontaminasi bakteri pada TC memiliki risiko transfusi sepsis dan kematian lebih besar daripada produk darah lainnya. ${ }^{10} \mathrm{Hal}$ ini diperparah karena pasien yang menerima TC sebagian besar mengalami immunosupresi sehingga rentan terhadap infeksi mikroorganisme. ${ }^{11}$

Pada penelitian sebelumnya berhasil mengidentifikasi bakteri dari produk darah yang menunjukkan keberadaan bakteri gram positif yaitu Staphylococcus hominis serta bakteri gram negatif yaitu Fusobacterium varium, Prophyromonas assaccharoltica, Sphingomonas paucimobilis, dan Propionibacterium acnes. ${ }^{3}$ Jenis bakteri yang terdeteksi di TC sebagian besar adalah bakteri gram positif yang berasal dari bakteri eksogen yang berasal dari kulit pendonor, tangan petugas pengambil darah, ataupun dari peralatan medis akibat dari aplikasi teknik yang kurang aseptis saat pengambilan darah dari pendonor, dan bakteri gram negatif yang berasal dari bakteremia donor yang memiliki risiko transfusi sepsis dan kematian. $^{8,12}$

Berdasarkan hal tersebut, maka penting dilakukan penelitian yang dapat mengetahui ada atau tidaknya bakteri kontaminan pada produk darah thrombocyte concentrate. Jenis bakteri yang teridentifikasi dapat digunakan sebagai informasi sifat patogenitas dan bermanfaat sebagai upaya pengamanan produk darah thrombocyte concentrate di Unit Donor Darah.

\section{BAHAN DAN CARA PENELITIAN}

Penelitian ini dilakukan di Unit Transfusi Darah Palang Merah Indonesia Kabupaten Sleman dan Laboratorium Mikrobiologi Pusat Studi Pangan dan Gizi Universitas Gadjah Mada Yogyakarta pada bulan Juli sampai September 2018.

$$
\text { Sampel penelitian sebanyak } 3
$$
kantong sampel TC digunakan pada penelitian ini berdasarkan 1\% produksi TC keseluruhan di UDD PMI Kabupaten Sleman. ${ }^{13}$ Sampel TC tersebut telah disimpan pada agitator dengan suhu $22-25^{\circ} \mathrm{C}$ dengan usia simpan 3-5 hari yang memiliki risiko proliferasi bakteri ketika terjadi kontaminasi. ${ }^{3}$ Sampel TC yang digunakan dipastikan homogen dan agregat di dalamnya tidak saling menempel.

\section{Inokulasi sampel pada media agar}

Media pertumbuhan bakteri yang digunakan adalah nutrient agar (NA). Sampel 
TC diinokulasi pada media NA steril secara aseptis dengan metode streak plate di cawan petri. Kultur TC pada media NA diinkubasi pada suhu $37^{\circ} \mathrm{C}$ selama 48 jam untuk kemudian diamati pertumbuhan bakteri. Adanya bakteri kontaminan pada TC diketahui dengan adanya pertumbuhan koloni bakteri pada kultur. ${ }^{14}$

\section{Analisis Data}

Pengamatan dilakukan pada kultur TC di media NA setelah inkubasi selama 48 jam. Adanya pertumbuhan koloni (cfu/ml) pada plate menunjukkan adanya reaksi positif. $^{15}$

\section{HASIL DAN PEMBAHASAN}

Penelitian analisis produk darah thrombocyte concentrate yang dilakukan ini bertujuan untuk mengetahui ada atau tidaknya kontaminasi bakteri pada produk darah TC yang pada beberapa penelitian sebelumnya didapatkan bakteri kontaminan. Apabila produk darah TC mengandung bakteri kontaminan maka akan berisiko terhadap pasien atau resipien karena terdapat potensi risiko transfusi yaitu bacterial sepsis yang memiliki gejala seperti muntah, syok septik, tachycardia, hipotensi, rigor, dan gejala potensial lain. ${ }^{9}$ Berdasarkan penelitian yang dilakukan, tiga kantong sampel produk darah TC diperoleh dari UDD PMI Kabupaten Sleman telah disimpan sesuai dengan standar penyimpanan TC yaitu pada suhu $22-25^{\circ} \mathrm{C}$ di atas agitator dengan masa simpan sampai dengan 5 hari pada kantong
TC yang berisi bahan pengawet untuk mempertahankan viabilitas trombosit. ${ }^{13}$ (Gambar 1). Produk darah TC yang dipilih untuk digunakan sebagai sampel telah disimpan selama 3-5 hari pada suhu ruang $\left(22-25^{\circ} \mathrm{C}\right)$ supaya apabila terdapat kontaminasi bakteri maka bakteri yang tumbuh akan semakin banyak ${ }^{(3)}$. Hal ini memungkinkan terjadinya pertumbuhan koloni bakteri pada media setelah dilakukan inokulasi.

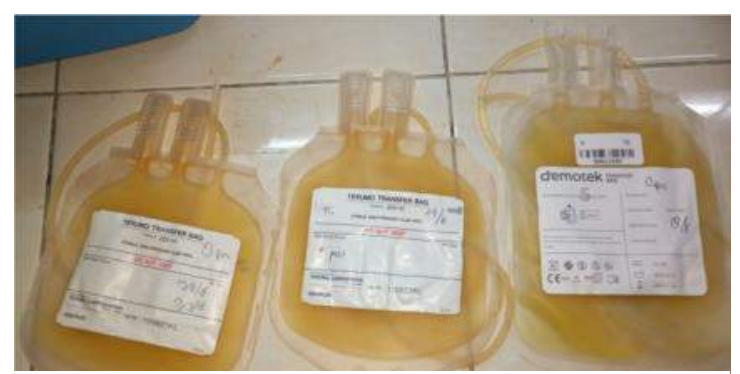

Gambar 2. Sampel thrombocyte concentrate

Berdasarkan hasil penelitian yang dilakukan diperoleh bahwa setelah dilakukan inokulasi dan inkubasi pada kultur sampel produk darah TC pada media NA tidak menunjukkan adanya pertumbuhan bakteri dengan tidak adanya koloni yang tumbuh di atas media NA (Gambar 2). Akibat tidak terdapat pertumbuhan bakteri pada media maka tidak dapat dilakukan karakterisasi, identifikasi bakteri, dan pengamatan sifat patogenisitas bakteri pada penelitian ini.

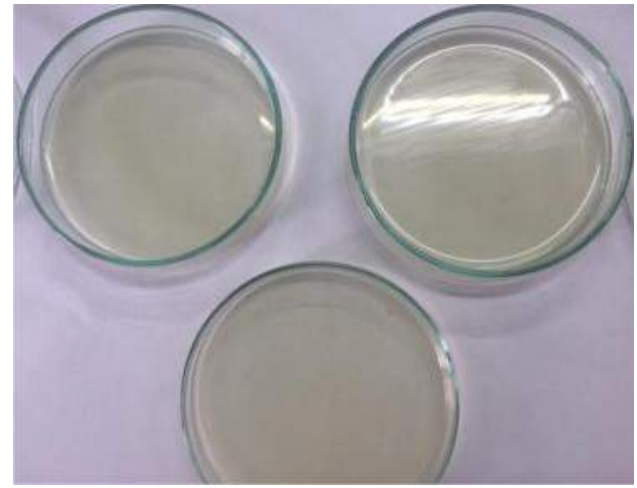

Analisis Produk Darah: Kontaminasi Bakteri pada Thrombocyte Concentrate Serafica Btari Christiyani Kusumaningrum ${ }^{1}$, Wiwit Sepvianti ${ }^{2}$ MIK P-ISSN 2252-3413, E-ISSN 2548-6268 setelah inkubasi 
Hal ini menunjukkan bahwa pada sampel produk darah thrombocyte concentrate yang digunakan tidak didapati adanya kontaminasi bakteri. Selain itu juga menunjukkan bahwa proses pemisahan TC yang dilakukan pada UDD PMI Kabupaten Sleman dilaksanakan secara aseptis dan peralatan yang digunakan dipastikan steril.

Pada penelitian sebelumnya didapatkan adanya kontaminasi bakteri Klebsiella pneumoniae, Staphylococcus aureus, Staphylococcus haemolyticus, dan Staphyloscoccus epidermidis pada TC..$^{3,4,9,12}$ Sumber kontaminasi tersebut berasal dari permukaan kulit saat pengambilan darah yang kurang aseptis karena keempat jenis bakteri yang ditemukan merupakan flora kulit. ${ }^{4}$ Pada penelitian yang dilakukan tidak didapatkan bakteri kontaminan TC yang tumbuh pada media padat, sehingga dapat diketahui bahwa kondisi mulai dari pengambilan darah, pengolahan TC, penyimpanan TC pada UDD PMI Kabupaten Sleman dilakukan secara aseptis sehingga tidak terdapat bakteri kontaminan yang dapat menimbulkan risiko transfusi pada pasien.

Kontaminasi bakteri juga dapat berasal dari bakteremia donor seperti pada penelitian sebelumnya yang menemukan Sphingomonas paucimobilis dan Propionibacterium acnes pada darah donor TC. ${ }^{3}$ Adanya bakteremia pada calon donor belum dapat dideteksi pada saat pemeriksaan atau sebelum dilakukan transfusi karena pada saat ini regulasi pemerintah hanya melakukan uji saring infeksi menular yang hanya mencakup infeksi penyakit Hepatitis C (HCV), Hepatitis B (HBV), Human Imunodeficiency Virus (HIV), dan Sypilis. ${ }^{13}$ Pada penelitian ini tidak didapati adanya kontaminasi bakteri pada produk TC yang juga menunjukkan bahwa pendonor TC tidak memiliki bakteremia. Namun, skrining dan deteksi bakteri pada pendonor dapat menurunkan risiko transfusi akibat kontaminasi bakteri pada produk TC dan sebagai upaya pengamanan produk darah. Beberapa pemeriksaan untuk mendeteksi bakteri pada unit produk darah sebelum transfusi yaitu kultur bakteri langsung dengan prinsip pengukuran produksi $\mathrm{CO}_{2}$ dan konsumsi $\mathrm{O}_{2}$, amplifikasi DNA bakteri, deteksi peptidoglikan bakteri, deteksi lipopolisakarida dan asam teikoat, serta deteksi viabilitas sel berdasarkan aktivitas esterase. ${ }^{16}$

\section{KESIMPULAN}

Berdasarkan hasil peneltian yang telah dilakukan maka dapat dirumuskan kesimpulan bahwa tidak terdapat pertumbuhan bakteri kontaminan yang berasal dari produk darah thrombocyte concentrate sehingga tidak dapat dilakukan identifikasi bakteri dan sifat patogenisitas bakteri. Hal ini menunjukkan bahwa produk darah TC aman untuk diberikan kepada calon penerima donor karena tidak terdapat risiko transfusi akibat kontaminasi. Hal tersebut dapat diperoleh dari pengambilan darah, 
pengolahan dan penyimpanan produk darah TC dilakukan secara aseptis dan sesuai prosedur. Namun, untuk meningkatkan upaya pengamanan darah, unit donor darah dapat melaksanakan skrining dan deteksi bakteri pada pendonor sebagai usaha menurunkan risiko transfusi.

\section{TERIMA KASIH}

Ucapan terima kasih disampaikan kepada DIPA Kopertis Wilayah V yang telah mendukung dengan Dana Bantuan Penelitian dengan nomor kontrak 017/LPPMGB/PEN/VI/2018.

\section{KEPUSTAKAAN}

1. Booth C, Allard S. Blood transfusion. Medicine (Baltimore) [Internet]. Elsevier; 2017 Apr 1;45(4):244-50. Available from: https://doi.org/10.1016/j.mpmed.2017.01. 014

2. Delaney M, Wendel S, Bercovitz RS, Cid J, Cohn C, Dunbar NM, et al. Transfusion reactions: prevention, diagnosis, and treatment. Lancet (London, England). England; 2016 Dec;388(10061):2825-36.

3. Sudiana IK. Analisis Produk Darah Thrombocyte Concentrate di Palang Merah Indonesia Surabaya ( Analysis of Blood Product Trombocyte Concentrate in Red Cross Blood Donor Unit Surabaya ). 2012;14(3).

4. Farzad BB, Farshad B, Zahra B, Nahid A, Mahsa KB. Bacterial contamination of platelet products in the Blood Transfusion Center of Isfahan, Iran. GMS Hyg Infect Control. 2016;11:Doc23.

5. Muller TH, Mohr H, Montag T. Methods for the detection of bacterial contamination in blood products. Clin Chem Lab Med. Germany; 2008;46(7):933-46.

6. Ketter P, Arulanandam B, Cap AP. Platelets Feeding Bacteria with Lactate during Room Temperature Storage: Mitigated By Refrigeration. Blood [Internet]. 2017 Dec 7;130(Suppl 1):2407 LP-2407. Available from: http://www.bloodjournal.org/content/130/ Suppl_1/2407.abstract

7. Velashjerdi Z, Deyhim MR, Razjou F, Eydi A. Effect of L-carnitine on platelet bacterial contamination and platelet metabolism during 5 days of storage of platelet concentrates. Blood-Journal 2019 Feb 1;15(1):1-11. Available from: http://bloodjournal.ir/article-1-1149en.html

8. He Z, Che J, Wang Q, Chen S, Chen Q, $\mathrm{Yu} \mathrm{L}$, et al. Bacterial contamination of platelet products in Dongguan Blood Center, Guangdong Province of China. 2018;(4):1-5.

9. Horth RZ, Jones JM, Kim JJ, Lopansri BK, Ilstrup SJ, Fridey J, et al. Fatal Sepsis Associated with Bacterial Contamination of Platelets - Utah and California , August 2017. 2018;67(25):718-22.

10. Levy JH, Neal MD, Herman JH. Bacterial contamination of platelets for transfusion: strategies for prevention. Crit Care [Internet]. 2018;22(1):271. Available from: https://doi.org/10.1186/s13054018-2212-9

11. Dickson $M$, Dinesh D. THE NEW ZEALAND. 2013;126(1374):12-21.

12. Astuti D, Maharani EA. Identifikasi bakteri yang mengontaminasi konsentrat trombosit. :61-7.

13. kemenkes-nomor-91-tahun-2015-tahun$2016 @$ peraturan.go.id [Internet]. Available from: http://peraturan.go.id/permen/kemenkesnomor-91-tahun-2015-tahun-2016.html

14. Bolarinwa RA, Aboderin OA, Odetoyin BW, Adegunloye AB. Bacterial contamination of blood and blood components in a tertiary hospital setting in Nigeria. 1996;1-6.

15. Hassall O, Maitland K, Pole L, Mwarumba S, Denje D, Wambua K. T r a $\mathrm{n} \mathrm{s} \mathrm{f}$ u s i o n c o m p i c at i o n s. 2009;49(December):2594-8.

16. Störmer $M$, Vollmer T. Diagnostic methods for platelet bacteria screening: current status and developments. 
Transfus Med Hemother [Internet]. 2013/12/30. S. Karger Verlag für Medizin und Naturwissenschaften $\mathrm{GmbH} ; 2014$ Feb;41(1):19-27. Available from: https://www.ncbi.nlm.nih.gov/pubmed/24 659944 